\title{
Vocational versus communicative competencies as predictors of job satisfaction : pharmacy assistants at the interface of professional and commercial work
}

Citation for published version (APA):

de Grip, A., Sieben, I. J. P., \& Stevens, F. C. J. (2006). Vocational versus communicative competencies as predictors of job satisfaction : pharmacy assistants at the interface of professional and commercial work. Researchcentrum voor Onderwijs en Arbeidsmarkt, Faculteit der Economische Wetenschappen. ROA Research Memoranda No. 3E https://doi.org/10.26481/umaror.200603E

Document status and date:

Published: 01/01/2006

DOI:

10.26481/umaror.200603E

Document Version:

Publisher's PDF, also known as Version of record

Please check the document version of this publication:

- A submitted manuscript is the version of the article upon submission and before peer-review. There can be important differences between the submitted version and the official published version of record.

People interested in the research are advised to contact the author for the final version of the publication, or visit the DOI to the publisher's website.

- The final author version and the galley proof are versions of the publication after peer review.

- The final published version features the final layout of the paper including the volume, issue and page numbers.

Link to publication

\footnotetext{
General rights rights.

- You may freely distribute the URL identifying the publication in the public portal. please follow below link for the End User Agreement:

www.umlib.nl/taverne-license

Take down policy

If you believe that this document breaches copyright please contact us at:

repository@maastrichtuniversity.nl

providing details and we will investigate your claim.
}

Copyright and moral rights for the publications made accessible in the public portal are retained by the authors and/or other copyright owners and it is a condition of accessing publications that users recognise and abide by the legal requirements associated with these

- Users may download and print one copy of any publication from the public portal for the purpose of private study or research.

- You may not further distribute the material or use it for any profit-making activity or commercial gain

If the publication is distributed under the terms of Article 25fa of the Dutch Copyright Act, indicated by the "Taverne" license above, 


\section{Vocational Versus Communicative Competencies as Predictors of Job Satisfaction \\ Pharmacy Assistants at the Interface of Professional and Commercial Work}

ROA-RM-2006/3E

Andries de Grip*, Inge Sieben* and Fred Stevens**

* Research Centre for Education and the Labour Market

** Department of Health Care Studies, Section of Medical Sociology, Maastricht University.

Research Centre for Education and the Labour Market

Faculty of Economics and Business Administration

Maastricht University

Maastricht, May 2006 
ISBN-10: 90-5321-437-2

ISBN-13: 978-90-5321-437-4

Sec06.037.doc 


\section{Contents}

Page

Abstract

Acknowledgment

1 Introduction 1

2 Theoretical background and hypotheses

3 Data and methods

4 Results

6

5 Discussion

6 Conclusions

References

Appendix A

Appendix B

Appendix C 



\begin{abstract}
We analyzed the effects of workers' competencies and job content on their overall, intrinsic, and extrinsic job satisfaction. We focused on pharmacy assistants, an occupational group that operates at the interface of professional health and commercial activities. This means that pharmacy assistants need both professional and customer-oriented competencies in their work. Results from a linked employer-employee survey showed that assistants with more communicative competencies were more satisfied with their job, whereas assistants with more pharmaceutical competencies were less satisfied. In addition, workers who performed tasks below their level of competence were more dissatisfied with their remuneration and career prospects, but not with the content of their job as such, than were other workers.
\end{abstract}

Keywords: job satisfaction, competencies, job content, intrinsic and extrinsic satisfaction

\title{
Acknowledgment
}

We would like to thank Jim Allen and Jasper van Loo, and participants of the EALE Conference (Lisbon, 2004) for their helpful comments on earlier draft of this paper. 


\section{Introduction}

Workers' job satisfaction is a major concern because low job satisfaction is associated with low performance, limited service quality, and reduced customer satisfaction (Batt \& Moyihan, 2002; Petty, McGee \& Cavender, 1984; Judge, Bono, Thoresesn \& Patton, 2001; Koys 2001). Moreover, low job satisfaction can cause health complaints (Waddell, 2004), burn-out (e.g. Jayaratne \& Chess, 1984), and a higher staff turnover (e.g. Price, 1977; Lachman \& Aranya, 1986; Shields \& Ward, 2001), creating substantial financial, social, and psychological costs for workers, organizations, and society. Indeed, workers' job satisfaction is highly important for the success and survival of an organization (Glisson \& Durick, 1988).

Although predictors of job satisfaction are well documented, to date little is known about the impact of workers' professional competencies. Workers' competencies may have both negative and positive effects on job satisfaction (e.g. Gordon \& Arvey, 1975). Adequate competencies are considered essential to a good job performance, which is conducive to higher satisfaction (Ganzach 2003). However, if individuals become over-competent, they may get bored, start complaining, or try to find more demanding work (Clark \& Oswald, 1996).

This study focuses on the relationship between the competencies and job satisfaction of pharmacy assistants in the Netherlands. We chose this particular occupational group because it operates at the interface of professional health and commercial activities (see Appendix A). This is particularly relevant because many professionals in health service organizations are nowadays facing a similar duality in their work and in the competencies required. Secondly, all pharmacy assistants are required by law to have graduated from a pharmacy assistant training program. The similar educational background of the participants means that we could focus on the relation between workers' job satisfaction and the workerjob match with respect to both specific professional skills and generic skills.

It can be assumed that people train to become pharmacy assistants because they are interested in the pharmaceutical aspects of their profession, and that the pharmaceutical aspects of their work mainly determine their intrinsic job satisfaction. However, most pharmacies are run as commercial businesses in the Netherlands and increasingly more drugs are supplied in ready-to-use formulations by the pharmaceutical industry, which means that pharmacy assistants nowadays spend less time preparing drugs and medications and more time interacting with customers and selling drugs at the counter. This usually requires communication skills rather than pharmaceutical skills. As a result, pharmacy assistants frequently face a duality in their job and need both pharmaceutical and communication skills to carry out their professional duties adequately. For this reason, pharmacy assistants can be considered 'representative' of other health service professions in which there is a similar duality between medical and 'customer-oriented' competencies required for good job performance. This duality of professional duties enabled us to investigate to what extent employees' vocational competencies and communicative competencies contribute to employees' job satisfaction. 
Our study builds on the research of Ganzach (1998 and 2003), who showed that job satisfaction is related to discrepancies between job desires and job reality invoked by differences between workers' abilities ${ }^{1}$ and both intrinsic and extrinsic rewards of their jobs. We investigated not only whether pharmacy assistants who performed tasks below their level of competence are likely to be less satisfied (Tsang, Rumberger \& Levin, 1991; Glisson \& Durick, 1988; Allen \& Van der Velden, 2001), but also whether assistants who performed tasks above their level of competence are less satisfied.

Previous research has shown that overall job satisfaction and domain-specific satisfaction may have different predictors (Ganzach, 2003). We therefore investigated the extent to which professional pharmaceutical and customer-oriented communicative competencies contribute to employees' overall job satisfaction. We then analyzed whether professional and communicative competencies are related to employees' intrinsic satisfaction (i.e. satisfaction with respect to the content of the job and working conditions) and extrinsic job satisfaction (i.e. satisfaction with respect to remuneration and career prospects). This distinction is important because a worker's competencies may affect both intrinsic job satisfaction (by means of the match between competencies and the content of the job and the working conditions) and extrinsic job satisfaction (by means of career prospects). Moreover, a lack of intrinsic job satisfaction may be compensated by high extrinsic job satisfaction because of higher wages.

\section{Theoretical background and hypotheses}

Workers' job satisfaction has been studied from the perspective of several disciplines: psychology (e.g. Locke, 1976), sociology (e.g. Kalleberg \& Loscocco, 1983), economics (e.g. Freeman, 1978), and management science (e.g. Hunt \& Saul, 1975). Overall, one can conclude that a mixture of work content, job autonomy, salary, and integration in the employing organization motivates workers. In terms of costs and benefits, psychological and social rewards may outweigh economic benefits, although the economic literature expects that 'compensating wages' correct for intrinsic rewards or disadvantages (Smith, 1776).

Several studies have focused on the relation between workers' level of education and their job satisfaction, showing that higher educated employees are less satisfied with their job than lower educated ones (Sloane \& Williams, 1996; Clark, Oswald \& Warr, 1996; Clark 1997; Ganzach 2003). The observation is usually taken to indicate that employees' job satisfaction depends on the match between job characteristics on the one hand, and prospects and aspirations on the other (Ganzach, 1998). For example, Tsang, Rumberger, and Levin (1991) and Hersch (1991) found that workers overqualified for their job had a lower job satisfaction, possibly because better-qualified workers have higher aspirations. This emphasizes the importance of matching the content of a job with the employee's expectations (O'Reilly \& Caldwell, 1981; Glisson \& Durick, 1988). Moreover, the chance of apathy and demoralization increases when well-qualified individuals work below their level of

1. Ganzach (1998 and 2003) distinguished between employees' intelligence and level of education. 
competence, have too many routine activities, or lose their professional autonomy vis-à-vis the employing organization (Hall, 1991; Scott, 1991). Indeed, job satisfaction, organizational commitment, and role ambiguity appear to be associated (see Glisson \& Durick, 1988 for an overview). Lachman and Aranya (1986) showed that job satisfaction is related to employees' occupational and professional commitment and to the way in which workers' expectations are met by the employing organization. They argue that professional workers develop occupational values that are highly important to job satisfaction. Thus, the way in which the organization is able to meet professionals' competencies and work expectations is crucial to job satisfaction. These expectations are either positively or negatively reinforced by the employing organization. Additionally, unambiguous responsibilities concerning tasks to be completed and the possibilities to use a broad range of competencies may be conducive to job satisfaction (Glisson \& Durick, 1988). These potential differences between job requirements and employee competencies can be subdivided into horizontal and vertical mismatches.

In the current study, horizontal mismatches refer to the distinction between pharmaceutical and communicative tasks and competencies. Because the current duties of pharmacy assistants are dependent more on their communicative, rather than pharmaceutical, skills, pharmacy assistants may become frustrated in their aspirations and professional commitment. Therefore, we expect that assistants who are more competent in their pharmaceutical tasks will be less satisfied with their job, ${ }^{2}$ whereas assistants with better communicative skills will be more satisfied with their job, because they have ample opportunities to exploit their excellence. Thus, we propose the following hypothesis on horizontal mismatches:

Hypothesis 1: Pharmacy assistants with more pharmaceutical competencies will be less satisfied with their job, whereas assistants with more communicative competencies will be more satisfied.

Vertical mismatch refers to the match between the perceived complexity of tasks and the level of competence. Pharmacy assistants are likely to become dissatisfied if their jobs are less challenging, or if they have to perform tasks that are above their level of competence. In line with this discussion of expected effects of vertical mismatches, we propose the following hypothesis:

Hypothesis 2: Pharmacy assistants performing tasks at their level of competence will be more satisfied with their job than assistants performing tasks below or above their level of competence.

As mentioned above, overall job satisfaction can be broken down into intrinsic and extrinsic job satisfaction. Ganzach (2003) showed that overall job satisfaction is mainly determined by

2. We here assume that assistants with lower competencies will not be less satisfied because they feel that they are not able to do their job adequately. As mentioned, all pharmacy assistants have completed vocational training, which guarantees that all assistants meet the required minimum job standards. Moreover, only a few assistants reported their pharmaceutical competencies as being "unsatisfactory". 
employees' intrinsic motivations. As horizontal and vertical mismatches predominantly refer to the content of the job, we expect that these mismatches will particularly affect pharmacy assistants' intrinsic job satisfaction. We therefore propose the following two hypotheses on intrinsic job satisfaction:

Hypothesis 3: Pharmacy assistants with more pharmaceutical competencies will have a lower intrinsic job satisfaction, whereas assistants with more communicative competencies will have a higher intrinsic job satisfaction.

Hypothesis 4: Pharmacy assistants performing tasks at their level of competence will have a higher intrinsic job satisfaction than assistants performing tasks below or above their level of competence.

The situation is more complex regarding extrinsic job satisfaction. When there is a horizontal mismatch between pharmacy assistants' competencies and the job requirements, a satisfactory salary may compensate for the lack of intrinsic job satisfaction. This is reflected in Adam Smith's (1776) notion of 'compensating wages'. However, this argument is not valid when a higher level of pharmaceutical competencies does not contribute to the performance of the pharmacy. This nowadays is the case in the Dutch pharmacies, which are run as commercial businesses delivering prefab drugs. Therefore, we expect that the remuneration of employees with more pharmaceutical competencies will not compensate for the lack of intrinsic job satisfaction. Moreover, there is no need to increase the wages of assistants with more communicative competencies, as these assistants will be rewarded by a higher intrinsic job satisfaction. However, vertical skill mismatches are expected to affect employees' external job satisfaction. When pharmacy assistants perform tasks below their level of competence, they may also be less satisfied with their rewards and career prospects, as these will, in general, be quite low. However, when they perform tasks above their level of competence they may be better rewarded. In the latter case, one would expect that assistants' extrinsic job satisfaction would be higher. Therefore, we propose the following two hypotheses on extrinsic job satisfaction:

Hypothesis 5: Pharmacy assistants' level of pharmaceutical or communicative competencies will not affect their extrinsic job satisfaction.

Hypothesis 6: Pharmacy assistants who perform tasks below their level of competence will have a lower extrinsic job satisfaction, whereas assistants performing tasks above their level of competence will have a higher extrinsic job satisfaction.

\section{Data and methods}

To test our hypotheses, we used data gathered during an employee survey among pharmacy assistants, held in November and December 2001. The survey was sent to a random sample of pharmacy assistants working in Dutch pharmacies. In total, 3,229 
assistants returned the written questionnaire (response rate 54\%). The data were matched with organizational information obtained from an employer survey among Dutch pharmacists held in the same period (response rate $42 \%$ ) and with administrative data on workforce and drug prescriptions. Combining the two surveys and the administrative data, we obtained linked data on 1,056 pharmacy assistants working in 388 pharmacies. All surveyed assistants were women. ${ }^{3}$ Because of partial non-response, we included 847 assistants in our analyses.

\section{Measures of job satisfaction}

We used three measures of job satisfaction: overall job satisfaction, intrinsic job satisfaction, and extrinsic job satisfaction. Overall job satisfaction was measured by asking assistants "All-in-all, how satisfied are you with your present job?" (answer categories: 'very satisfied', 'satisfied', 'not very satisfied', and 'not satisfied at all'). To obtain information about intrinsic job satisfaction, assistants were asked to rate their satisfaction with (a) work content (b) work autonomy (c) work hours, (d) work pressure, (e) safety at work, (f) work atmosphere, and (g) pharmacy management. Cronbach's alpha was .74. To obtain information about extrinsic job satisfaction, assistants were asked to rate (a) wage level and (b) career prospects. Cronbach's alpha was .54. Both intrinsic and extrinsic job satisfaction were measured on a four-point scale with the same answer categories as for overall job satisfaction. Items and descriptive statistics of overall, intrinsic, and extrinsic job satisfaction are given in appendix $B$ (Table B.1).

\section{Measures of competencies}

Pharmacy assistants were asked to rate their pharmaceutical and communicative competencies on a scale varying between 1 (low score) and 10 (high score). Items on pharmaceutical competencies were (a) knowledge of medicines, (b) knowledge of syndromes, (c) dispensing medicines, and (d) preparing medicines; Cronbach's alpha was .70. Communicative competencies were (a) communication skills and (b) inter-collegial relationships; Cronbach's alpha was .60. (See Appendix B Table B.2 for items and descriptives). The pharmacy assistants were also asked whether they performed tasks above or below their level of competence.

\section{Personal, work, and organizational characteristics}

Personal, work, and organizational characteristics were included as control variables in the analyses (cf. Hunt \& Saul, 1975; Idson, 1990; Losocco \& Spitze, 1990, and Ganzach, 2003). Work experience was measured in years of employment as a pharmacy assistant. Tenure is a dichotomous variable indicating whether or not the assistant had a permanent contract. Employment status (fullime versus part-time) was assessed in terms of hours worked per week. Income was computed as the gross monthly salary in euros when working fulltime (i.e. 36 hours a week). Poor working conditions were assessed by asking respondents whether they experienced 'regularly', 'sometimes', or 'never' (a) high work pressure, (b) physical strain, (c) mental strain, (c) poor physical work conditions, and (d) monotonous work. Cronbach's alpha was .56. Organizational variables included pharmacy size, technological

3. The only two male pharmacy assistants in the survey were not included in our analyses. 
change, and organizational change. Pharmacy size was categorized in four classes based on the number of prescription lines delivered in a year: ${ }^{4}$ small (less than 60,000 prescriptions a year), middle $(60,000-80,000)$, large $(80,000-100,000)$, and very large (more than 100,000 prescription lines a year). Technological change was indicated by a positive answer on the question whether a new computer system had been introduced in the past year. Organizational change was indicated by the occurrence of a reorganization, merger, or cooperation between pharmacies in the past year.

\section{Methods}

We established ordered probit models for overall job satisfaction and intrinsic and extrinsic job satisfaction. Ordered probit is a technique for analyzing dependent variables that take only a finite number of values possessing a natural ordering, which is conceptually close to linear regression techniques (McKelvey \& Zaviona, 1975). In our ordered probit models, the discrete but ordinal nature of job satisfaction was modeled by denoting three job satisfaction outcomes $\left(y_{i}=0 \text { "not satisfied", } y_{i}=1 \text { "satisfied", and } y_{i}=2 \text { "very satisfied") }\right)^{5}$ for individual i. This lead to the following estimated model:

$y_{i}^{*}=\beta_{p c} x_{p c}+\beta_{c c} x_{c c}+\beta_{t b} x_{t b}+\beta_{t a} x_{t a}+\beta_{i} x_{i}+u_{i}$

where $\mathrm{y}_{i}{ }^{*}$ is the unobserved job satisfaction outcome, xpc the assistant's pharmaceutical competencies, xcc the assistant's communicative competencies, xtb performing tasks below the level of competence, xta performing tasks above the level of competence, $x_{i}$ a vector of control variables described above, $\beta_{p c}, \beta_{c c}, \beta_{t b}, \beta_{t a}$, and $\beta_{i}$ vectors of parameters to estimate, and $u_{i}$ the error term.

\section{Results}

\section{Descriptive statistics}

Most pharmacy assistants were satisfied with their job (see Table 1). On average, they were more satisfied with job content and working conditions (intrinsic job satisfaction) than with remuneration and career prospects (extrinsic job satisfaction). Assistants were more critical of their pharmaceutical skills than of their communication skills, awarding these skills scores of 7.30 and 7.84 on a 10-point scale, respectively. Pearson correlation between both competencies was .41 (see Appendix C), reflecting that these competencies are not completely overlapping.

4. Information on the number of prescription lines delivered to clients was retrieved from administrative data. The number of prescription lines is an important indicator of pharmacy sales. In 2001, pharmacies received $€ 5.67$ per prescription line from the government.

5. Since only a few pharmacy assistants report being "not satisfied at all" (see Table B.1 in Appendix B), we combined this category with the category of being "not very satisfied". This implies that the dependent variable has three categories: 'not satisfied', 'satisfied', and 'very satisfied'. 
Sixteen percent of the pharmacy assistants performed tasks below their level of competence, and $15 \%$ tasks above their level of competence. Analysis of competencies and task performance (see Appendix C) suggested that pharmaceutical competencies, more than communicative competencies, were associated with performing tasks both above and below the assistants' level of competence.

Table 1

Descriptive statistics

Mean Standard deviation

Job satisfaction

Overall job satisfaction (1-4)

3.17

.64

Intrinsic job satisfaction (1-4)

Extrinsic job satisfaction (1-4)

2.53

.68

Competencies

Pharmaceutical competencies (1-10)

7.30

.74

Communicative competencies (1-10)

7.84

Performing tasks below or above level of competence

Tasks below level of competence (yes/no)

Tasks above level of competence (yes/no)

Personal and work characteristics

Work experience as pharmacy assistant (in years)

Permanent contract (yes/no)

Working hours per week

Monthly income $(x € 1,000)$

26.66

1.80

Poor working conditions (yes/no)

Organizational characteristics

Firm size

- Small pharmacy (yes/no)

- Intermediate pharmacy (yes/no)

- Large pharmacy (yes/no)

- Very large pharmacy (yes/no)

The respondents had, on average, 13 years of work experience as a pharmacy assistant: 8 years in the present job and 5 years elsewhere. Nearly all assistants had permanent (tenured) positions. Pharmacy assistant pay scales were based on the salary scales defined in the collective bargaining agreement for Dutch pharmacies. The average gross monthly income was $€ 1,800$ when working fulltime (i.e. 36 hours per week); however most assistants worked part-time (mean 27 hours/week). Twenty-two percent of the respondents reported poor working conditions, such as regularly working under high time pressure, or doing physically or mentally strenuous work. Twenty-six percent of the respondents worked in a small pharmacy and $17 \%$ in a very large pharmacy. Only $17 \%$ of the respondents reported technological changes in the pharmacy (introduction of a new computer system in the past year), whereas organizational changes were much more common, being reported by more than $50 \%$ of the respondents. 


\section{Overall job satisfaction}

Table 2 shows the estimation results of the ordered probit analysis on overall job satisfaction. This analysis revealed that communication competencies were positively correlated with job satisfaction, whereas pharmaceutical competencies were negatively correlated with overall job satisfaction. This fully supports our first hypothesis. In contrast, overall job satisfaction was not correlated with the performance of tasks below or above the assistant's level of competence. ${ }^{6}$ Our second hypothesis therefore has to be rejected.

Table 2

Results of ordered probit regression analyses on overall job satisfaction ( $n=847)$

B

(s.e.)

Competencies

Pharmaceutical competencies

Communicative competencies

$-.207^{*}$

$.449^{\star \star \star}$

Performing tasks below or above level of competence

Tasks below level of competence

$-.316$

$-.181$

Tasks above level of competence

(181

Personal and work characteristics

Work experience as pharmacy assistant

$-.030$

.001

$-.114$

Permanent contract

.003

.083

Monthly income

$-3.518^{\star * *}$

Organizational characteristics

Firm size

- Small pharmacy (ref.)

- Intermediate pharmacy

$371^{-}$

$.486 * *$

$.534^{\star \star}$

.042

- Very large pharmacy

$-.428 * *$

Organizational change in past year

$-1.100$

$2.297^{\text {** }}$

$(-)$

Constant 1

.206

Nagelkerke Pseudo R2

$p<0.10 ;{ }^{* \star} p<0.05 ;{ }^{* \star *} p<0.01$

Not surprisingly, overall job satisfaction was negatively correlated with poor working conditions (cf. Losocco \& Spitze, 1990). In addition, assistants working in small pharmacies and in pharmacies that experienced organizational change during the past year were less satisfied with their job (cf. Handel, 2005).

6. In this respect, it could be interesting to look at interactions between the competencies and the level of tasks of pharmacy assistants, as assistants with more competencies might do higher-level tasks, whereas assistants with lower competencies might perform lower-level tasks. Estimates including these interaction terms did not provide any additional significant results. 
Intrinsic and extrinsic job satisfaction

Analysis of intrinsic and extrinsic job satisfaction revealed that the respondents' communicative competencies were positively correlated with intrinsic job satisfaction (i.e. job content and related conditions) but not with extrinsic job satisfaction (remuneration and career prospects) (see Table 3). These results confirm the second part of the third and fifth hypotheses. In addition, assistants' level of pharmaceutical competencies was not correlated with extrinsic job satisfaction, which supports the first part of our fifth hypothesis. However, in conflict with the first part of the third hypothesis, assistants' levels of pharmaceutical competencies were not negatively correlated with intrinsic job satisfaction. Performing tasks below one's level of competence was negatively correlated with extrinsic job satisfaction, consistent with our sixth hypothesis. There was, however, no support for the other predictions of hypotheses 4 and 6 .

Table 3

Result of ordered probit regression analyses on intrinsic and extrinsic job satisfaction ( $n=847)$

$\begin{array}{ll}\text { Intrinsic job } & \text { Extrinsic job } \\ \text { satisfaction } & \text { satisfaction } \\ \text { B } \quad(\text { s.e. }) & \text { B }\end{array}$

B (s.e.)

B (s.e.)

\section{Competencies}

Pharmaceutical competencies

Communicative competencies

$\begin{array}{lll}.069 & .076 & -.036 \\ .250^{\star *} & .077 & -.025\end{array}$

Performing tasks below or above level of competence

Tasks below level of competence

$\begin{array}{lll}-.193 & .128 & -.360^{*}\end{array}$

Tasks above level of competence

$$
-.030
$$

.138

.266

Personal and work characteristics

Work experience as pharmacy assistant

Work experience as pharmacy assistant squared

Permanent contract

Working hours per week

$-.033$

$.023-.104^{\star *}$

.001

.001

$.002^{\star *}$

.225

.242

$-.391$

$(.001)$

Monthly income

$$
-.007
$$

.007

$-.031^{\star \star}$

Poor working conditions

Organizational characteristics

$228-2.289^{\star \star *}$

Firm size

- Small pharmacy (ref.)

- Intermediate pharmacy

- Large pharmacy

- Very large pharmacy

Technological change in past year

Organizational change in past year

\begin{tabular}{llll}
- & - & \multicolumn{1}{c}{-} & $(-)$ \\
.021 & .123 & .047 & $(.185)$ \\
.197 & .134 & .090 & $(.200)$ \\
$.269^{\star}$ & .150 & $.533^{\star *}$ & $(.226)$ \\
-.059 & .129 & .163 & $(.195)$ \\
& .096 & .054 & $(.144)$ \\
-.077 & & & \\
.295 & .715 & -1.793 & $(1.094)$ \\
$3.283^{\star * *}$ & .727 & 1.583 & $(1.099)$ \\
.216 & & .126 &
\end{tabular}

Constant 1

Constant 2

Nagelkerke Pseudo $R^{2}$

${ }^{*} p<0.10 ;{ }^{* \star} p<0.05 ;{ }^{* \star *} p<0.01$

Several personal and work characteristics were associated with intrinsic and extrinsic job satisfaction (Table 3). More work experience was associated with less satisfaction with 
remuneration and career prospects, although this effect leveled in time, as indicated by the square term. Monthly income was positively correlated with assistants' satisfaction with wages and career prospects. In addition, working fewer hours was associated with less extrinsic job satisfaction. Poor working conditions had a strong negative effect on both intrinsic and extrinsic job satisfaction. Of the organizational characteristics, only the size of the pharmacy was correlated with job satisfaction: respondents working in large pharmacies reported more intrinsic and extrinsic job satisfaction.

\section{Discussion}

In this study, we analyzed the effects of pharmacy assistants' competencies and job content on job satisfaction. In line with our first hypothesis regarding horizontal mismatches, we found that more competent workers were more satisfied with their job. Pharmacy assistants with higher levels of communicative competencies had higher overall satisfaction scores, but were in particular more satisfied with the intrinsic qualities of their work. Pharmaceutical competencies, on the other hand, had a negative effect on overall job satisfaction. These results clearly reflect the shift from pharmaceutical tasks to communicative tasks in the work of pharmacy assistants. Thus communicative competencies appear to be more important to job satisfaction than specific vocational competencies (cf. Handel, 2005).

Our 'vertical mismatches' hypothesis that pharmacy assistants who performed tasks at their level of competence would be more satisfied with their job than assistants who performed tasks below or above their level of competence was not confirmed. We did, however, find that assistants who performed tasks below their level of competence were less satisfied with their wages and career prospects, but they were not dissatisfied with the content of their job as such. As we expected, neither communicative nor pharmaceutical competencies were associated with extrinsic job satisfaction. This indicates that assistants' expectations of remuneration and career prospects were in line with their competencies. It also indicates that 'compensating wages' do not correct for intrinsic rewards or disadvantages, as suggested by economic theory (Smith, 1776), since this would imply that (lower) intrinsic job satisfaction could be substituted by (higher) extrinsic job satisfaction.

Obviously, the 'quality of working life' has a major role in predicting job satisfaction. Poor working conditions, work experience, working hours, monthly income, and pharmacy size primarily influenced assistants' extrinsic job satisfaction. Moreover, overall job satisfaction was negatively affected by changes in the organization of the pharmacy. This shows that pharmacy assistants' job satisfaction is affected by discontinuities in their job content due to changes in the organization of their work but not by technological changes, because the introduction of a new computer system or software programs did not affect assistants' job satisfaction (cf. Neuman \& Weiss, 1995). 


\section{Conclusions}

Although several other studies have investigated the effects of workers' level of education on job satisfaction (e.g. Ganzach, 2003), to date little is known about the impact of horizontal job-worker mismatches with respect to both workers' specific professional competencies and their more general competencies. The latter is the more important because of the altered skills demands of various occupations (Green et al., 2000). Moreover, the results of our study shed light on the effects of vertical mismatches on job satisfaction among workers employed within their own occupational domain. In this way, our study builds on the literature on effects of 'overeducation' on workers' job satisfaction. (e.g. Tsang, et al., 1991).

Comparing the results of different satisfaction models (i.e. overall, intrinsic, and extrinsic job satisfaction), we observed that intrinsic job satisfaction was similar to overall job satisfaction in terms of the effect of individual competencies. Consequently, our study confirms Ganzach's (2003) conclusion that people are primed to think about intrinsic rather than extrinsic sources of satisfaction. This means that although higher wages positively affect assistants' extrinsic job satisfaction, they do not compensate for the negative effects of employees' pharmaceutical competencies, nor do they induce a 'wage penalty' for the positive effect of their communicative competencies on their intrinsic job satisfaction.

The occupation of pharmacy assistant in the Netherlands offers an interesting opportunity to analyze whether workers' job satisfaction is related to the duality of skills demanded in the job. This increasing duality is a recent trend in many occupations in which interactions with customers become more important, and in which traditionally required vocational skills become less important. In this respect, our findings are relevant for other health care occupations (see for example Liu et al., 2005), as well as for occupations in different institutional sectors (see for example McNeely 1992). However, all occupations have specific idiosyncratic characteristics that may affect research outcomes, and thus research focusing on different occupational groups will contribute to our insight into the effects of changing skills demands in the labor market on workers' job satisfaction.

\section{References}

Allen, J. \& Van der Velden, R. (2001). Educational mismatches versus skills mismatches: effects on wages, job satisfaction, and on-the-job-search, Oxford Economic Papers, 53: 434-452.

Batt, R. \& L. Moynihan (2002). The Viability of Alternative Call Centre Production Models. Human Resource Management Journal, 12: 14-34.

Clark, A.E. (1997). Job Satisfaction and Gender. Why are women so Happy at Work? Labour Economics 4(4), 341-372.

Clark, A.E. \& A.J. Oswald (1996). Satisfaction and Comparison Income. Journal of Public Economics, 61: 359-381. 
Clark, A.E., A. Oswald \& P. Warr (1996). Is Job Satisfaction U-Shaped in Age? Journal of Occupational and Organizational Psychology, 69: 57-81.

De Grip, A., M. Hensen \& I. Sieben (2003). De arbeidsmarkt voor apothekersassistenten tot 2010: een toekomstverkenning. [The labour market for pharmacist's assistants till 2010: an exploration of the future]. Maastricht: ROA.

Freeman, R. (1978). Job Satisfaction as an Economic Variable. American Economic Review, 68: $135-141$.

Ganzach, Y. (1998). Intelligence and Job Satisfaction. Academy of Management Journal, 41: 526-539.

Ganzach, Y. (2003). Intelligence, Education, and Facets of Job Satisfaction. Work and Occupations, 30: 97-122.

Glisson, Ch. \& M. Durick (1988). Predictors of Job Satisfaction and Organizational Commitment in Human Service Organization. Administrative Science Quarterly, 33: 6181.

Gordon, M.E. \& R.D. Arvey (1975). The Relationship between Education and Satisfaction with Job Content. Academy of Management Journal, 18: 888-892.

Green, F., D. Ashton, B. Burchell, B., Davies \& A. Felstead (2000). "Are British Workers Becoming More Skilled?", in: L. Borghans, L. \& A. De Grip (eds), The Overeducated Worker? The Economics of Skill Utilization, Cheltenham: Edward Elgar, 77-106.

Hall R.W. (1991). Organizations: structures, processes outcomes. Englewood Cliffs, NJ: Prentice-Hall NJ.

Handel, M.J. (2005). Trends in Perceived Job quality, 1989 to 1998. Work and Occupations, 32: 66-94.

Hersch, J. (1991). Education match and job match. Review of Economics and Statistics, 73: 140-144.

Hunt, J.W. \& P.N. Saul (1975). The relationship of Age, Tenure, and Job Satisfaction in Males and Females. Academy of Management Journal, 18: 690-702.

Idson, T.L. (1990). Establishment Size, Job Satisfaction and Structure of Work. Applied Economics, 11: 606-628.

Jayaratne, S. \& W.A. Chess (1984). Job Satisfaction, Burnout and Turnover: A National Survey. Social Work, 29: 448-453. 
Judge, T., J.E. Bono, C.J. Thoresen \& G.K. Patton (2001), The Job Satisfaction-Job Performance Relationship: A Qualitative and Quantitative Review. Psychological Bulletin, 127: 376-407.

Kalleberg, A.L. \& K.A. Loscocco (1983). Aging, Values and Rewards Explaining Age Differences in Job Satisfaction. American Sociological Review, 48: 78-90.

Koys, D.J. (2001). The Effects of Employee Satisfaction, Organizational Citizenship Behaviour, and Turnover on Organizational Effectiveness: A Unit-Level Longitudinal Study. Personnel Psychology, 54: 101-114.

Lachman, R. \& N. Aranya (1986). Evaluation of Alternative Models of Commitments and Job Attitudes of Professionals. Journal of Occupational Behaviour, 7: 227-243.

Liu C-M, Chien C-W, Chou P, Liu J-H, Chen VT-K, Wei J, et al. (2005). An analysis of job satisfaction among physician assistants in Taiwan. Health Policy , 73: 66-77.

Locke, E.A. (1976). „The Nature and Causes of Job Satisfaction”, in M.D. Dunette (eds.), Handbook of Industrial and Organizational Psychology. Chicago: Rand McNally.

Losocco, K.A. \& G. Spitze (1990). Working conditions, social support, and the well-being of female and male factory workers. Journal of Health and Social Behavior, 313-327.

McKelvey, R.D. \& R. Zavoina (1975). A Statistical Model for the Analysis of Ordinal Level Dependent Variables. Journal of Mathematical Sociology, 4: 103-120.

McNeely R.L. (1992) "Job satisfaction in the public social services: Perspectives on structure, situational factors, gender and ethnicity"' In: Hasenfeld Y (ed.). Human services as complex organizations. London: Sage.

Mincer, J. (1974) Schooling, Experience and Earnings, New York: National Bureau of Economic Research.

Neuman, S. \& A. Weiss (1995). On the Effects of Schooling Vintage on Experience-Earnings Profiles: Theory and Evidence. European Economic Review, 39: 943-955.

O'Reilly, Ch.A. \& D.F. Caldwell (1981). The Commitment and Job Tenure of New Employees: Some Evidence of Postdecisional Justification. Administrative Science Quarterly, 26: 597-616.

Petty, M.M., G.W. McGee \& J.W. Cavender (1984). A Meta-Analysis of the Relationships Between Individual Job Satisfaction and Individual Performance. Academy of Management Review, 9: 712-721.

Price J.L. (1977) A study of organizational turnover. Ames, lowa: University of lowa Press. 
Scott W.R. (1991) Organizations: rational, natural and open systems. Englewood-Cliffs, NJ: Prentice-Hall.

Shields, M. \& M. Ward (2001). Improving Nurse Retention in the National Health Service in England: the Impact of Job Satisfaction on Intentions to Quit. Journal of Health Economics, 20: 677-701.

Sloane, P. \& H. Wiliams (1996). Are 'Overpaid' Workers Really Unhappy? Labour, 10, 3-15.

SFK (2002). Feiten en cijfers 2002 [Facts and Figures 2002]. Den Haag: SFK.

Smith, A. (1776). The Wealth of Nations, Edinburgh: Adam \& Ch. Black.

Tsang, M.C., R.W. Rumberger \& H.M. Levin (1991). The Impact of Surplus Schooling on Work Productivity. Industrial Relations, 30: 209-228.

Waddell G. (2004) The back pain revolution. Edinburgh, London: Churchill Livingstone. 


\section{Appendix A}

In the Netherlands, registered drugs can only be obtained from pharmacies on presentation of a family doctor's prescription. Although Dutch pharmacies are strongly regulated they are nevertheless truly independent, for-profit firms. About $20 \%$ of Dutch pharmacies are part of a (international) wholesaling company. In 2001, the 1,631 pharmacies distributed $€ 3,419$ million worth of drugs (SFK, 2002). In this respect, it should be noted that in the Netherlands, non-registered drugs are usually supplied by commercial drugstores and contribute little to pharmacy sales.

Compared with other European countries, the Dutch population does not consume many drugs. The average pharmacy serves 9,000 patients and has 8.7 FTE staff: one pharmacist, under whose supervision the drugs are prepared and distributed, 5.8 FTE pharmacy assistants, and about 1.9 FTE other employees (usually cleaning personnel and administrative staff). Overall, Dutch pharmacies employ 12,640 pharmacy assistants (De Grip, Hensen \& Sieben, 2003). It is the pharmacy assistants who usually deliver the drugs and have contacts with the customers. Table A.1 gives an overview of their tasks. Pharmacy assistants spend about $54 \%$ of their time on activities related to communicative competencies (counter contacts and dispensing medicines) and 39\% on tasks related to pharmaceutical competencies (ordering, preparing, and monitoring medicines).

Table A.1

Pharmacist's assistants' tasks at work

Tasks

Percentage of workweek $(\%)$

Basic tasks: Standard counter contacts $\quad 30.3$

Basic tasks: Dispensing medicines $\quad 23.6$

Basic tasks: Monitoring medicines $\quad 12.1$

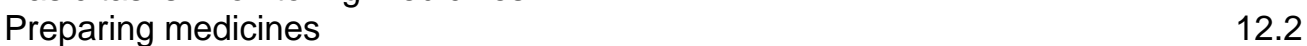

Ordering and delivery of medicines $\quad 8.8$

Pharmaceutical patient care $\quad 5.9$

Clerical tasks $\quad 4.2$

Financial tasks $\quad 1.4$

$\begin{array}{ll}\text { Other tasks } & 3.3\end{array}$ 


\section{Appendix B}

Table B.1

Pharmacy assistants' overall, intrinsic, and extrinsic job satisfaction

$\begin{array}{cc}\text { Very satisfied } & \text { Satisfie } \\ (\%) & \mathrm{d}\end{array}$

$(\%)$
Not very
satisfied

$(\%)$
Not satisfied at

all

$(\%)$

$\begin{array}{lrrrr}\text { Overall job satisfaction } & 29.0 & 59.7 & 10.3 & 1.0 \\ \text { Intrinsic job satisfaction } & 10.9 & 79.6 & 9.3 & 0.2 \\ \text { Work content } & 20.2 & 68.4 & 9.7 & 1.6 \\ \text { Work autonomy } & 34.5 & 61.8 & 3.5 & 0.2 \\ \text { Work hours } & 28.6 & 65.5 & 5.5 & 0.5 \\ \text { Work pressure } & 5.5 & 54.8 & 31.4 & 8.2 \\ \text { Safety at work } & 12.8 & 73.1 & 13.0 & 1.0 \\ \text { Work atmosphere } & 31.1 & 56.3 & 11.0 & 1.5 \\ \text { Pharmacy management } & 14.7 & 53.4 & 23.7 & 8.2 \\ \text { Extrinsic job satisfaction } & 4.7 & 49.2 & 40.4 & 5.6 \\ \text { Wage level } & 2.9 & 38.3 & 44.5 & 14.3 \\ \text { Career perspectives } & 4.2 & 41.7 & 38.6 & 15.5\end{array}$

Table B.2

Pharmacy assistants' pharmaceutical and communicative competencies: mean scores (scale 1-10), standard deviations, and percentages scoring 6 or lower

\begin{tabular}{|c|c|c|c|}
\hline & Mean & s.d. & $\begin{array}{c}6 \text { or lower } \\
(\%)\end{array}$ \\
\hline Pharmaceutical competencies & 7.30 & .74 & 4.8 \\
\hline Knowledge on medicines & 7.21 & .85 & 14.2 \\
\hline Knowledge on syndromes & 6.77 & .91 & 32.8 \\
\hline Dispensing medicines & 7.75 & .95 & 5.0 \\
\hline Preparing medicines & 7.46 & 1.34 & 13.6 \\
\hline Communicative competencies & 7.84 & .67 & .7 \\
\hline Communication skills & 7.66 & .82 & 4.9 \\
\hline Inter-collegial relationships & 8.02 & .76 & 1.3 \\
\hline
\end{tabular}




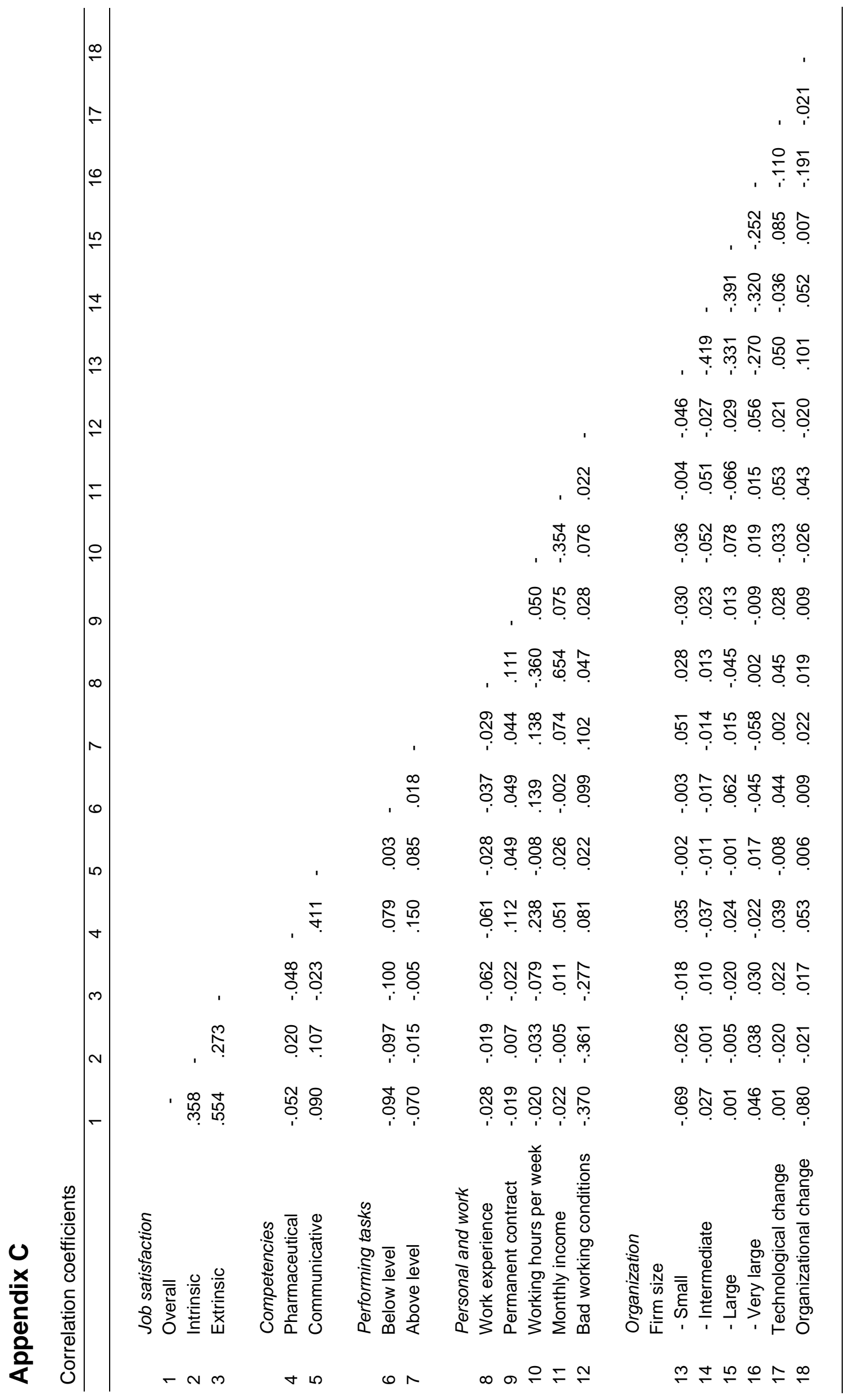

